\title{
Screening of metabolites from endophytic fungi of some Nigerian medicinal plants for antimicrobial activities
}

\author{
Peter M. Eze ${ }^{1 \star}$, Joy C. Nnanna ${ }^{1}$, Ugochukwu Okezie ${ }^{1}$, Happiness S. Buzugbe ${ }^{1}$, Chika C. Abba ${ }^{2}$, \\ Chidimma R. Chukwunwejim ${ }^{3}$, Festus B. C. Okoye ${ }^{2}$ and Charles O. Esimone ${ }^{1}$
}

\begin{abstract}
Endophytic fungi associated with Nigerian plants have recently generated significant interest in drug discovery programmes due to their immense potential to contribute to the discovery of new bioactive compounds. This study was carried out to investigate the secondary metabolites of endophytic fungi isolated from leaves of Newbouldia laevis, Ocimum gratissimum, and Carica papaya. The plants were collected from Agulu, Anambra State, South-East Nigeria. Endophytic fungal isolation, fungal fermentation; and extraction of secondary metabolites were carried out using standard methods. The crude extracts were screened for antimicrobial activities using the agar well diffusion method, and were also subjected to high performance liquid chromatography (HPLC) analysis to identify their constituents. A total of five endophytic fungi was isolated, two from N. laevis (NL-L1 and NL-L2), one from O. gratissimum (SL-L1), and two from C. papaya (PPL-LAC and PPL-LE2). In the antimicrobial assay, the extracts of NL-L2, SL-L1, and PPL-LE2 displayed mild antibacterial activity against both Gram negative and Gram positive test bacteria. PPL-LAC extract showed mild activity only against $S$. aureus, while no antimicrobial activity was recorded for NL-L1 extract. All the endophytic fungal extracts showed no activity against the test fungi C. albicans and A. fumigatus. HPLC analysis of the fungal extracts revealed the presence of ethyl 4-hydroxyphenyl acetate and ferulic acid in NL-L1; ruspolinone in NL-L2; protocatechuic acid, scytalone, and cladosporin in SL-L1; indole-3-acetic acid and indole-3carbaldehyde in PPL-LE2; and indole-3-acetic acid in PPL-LAC. The findings of this study revealed the potentials possessed by these plants as source of endophytes that express biological active compounds. These endophytes hold key of possibilities to the discovery of novel molecules for pharmaceutical, agricultural and industrial applications.
\end{abstract}

Keywords: Endophytic fungi, Newbouldia laevis, Ocimum gratissimum, Carica papaya, secondary metabolites, antimicrobial activity

'Department of Pharmaceutical Microbiology and Biotechnology, Faculty of Pharmaceutical Sciences, Nnamdi Azikiwe University, Awka, Nigeria

${ }^{2}$ Department of Pharmaceutical and Medicinal Chemistry, Faculty of Pharmaceutical Sciences, Nnamdi Azikiwe University, Awka, Nigeria

${ }^{3}$ Department of Pharmaceutics and Pharmaceutical Technology, Faculty of Pharmaceutical Sciences, Enugu State University of Sciences and Technology, Enugu, Nigeria

*Corresponding author: P. M. Eze E-mail: ezep2004@hotmail.com

DOI: 10.2478/ebtj-2019-0002

(C) 2019 Authors. This work was licensed under the Creative Commons AttributionNonCommercial-NoDerivs 4.0 License.

\section{Introduction}

Due to the relationships that endophytes seem to have with their host plants, they make a myriad of biologically active compounds. These compounds can be classified as antibiotics, antioxidants, anticancer agents, volatile antimicrobial agents, immunosuppressive compounds, plant growth promoting agents, and insecticides (1). It has been reported that endophytes possess the ability to produce the same or similar chemicals as those originating from their host plants $(2,3)$. This presents endophytic microorganisms as potential alternatives to plants in the search for biologically active molecules.

Newbouldia laevis (Bignoniaceae), Ocimum gratissimum (Lamiaceae), and Carica papaya (Caricaceae) are medicinal plants commonly found in Nigeria. These plants have been used ethnomedicinally in the treatment of several disease conditions including ulcers, burns, diarrhea, bleeding, haemorrhoids, dysentery, abdominal pains, cough, colds, pruritus, stress, headache, pneumonia, conjunctivitis, diabetes mellitus, epilepsy and convulsions (4-12).

Various scientific studies have shown that $N$. Laevis possesses antimicrobial, antidiabetic, antioxidant, and antimalarial activities (11-14). O. gratissimum has been reported to show antidiabetic, antioxidant, anxiolytic, sedative, anti-inflammatory, hepatoprotective, antitumor, gastroprotective, hypolipidemic, insecticidal, nematicidal, 
and antibacterial activities (4,5,15-27). Also, scientific reports have revealed that $C$. papaya possesses immunomodulatory, antimicrobial, anti-inflammatory, antihelmintic, anticancer, wound healing, anti-fertility, abortifacient, diuretic, antihypertensive and antimalarial properties (10, 28-39).

In our search for biologically active molecules from endophytic fungi associated with Nigerian plants, this present study was carried out to investigate the secondary metabolites of endophytic fungi isolated from three Nigerian medicinal plants N. laevis, O. gratissimum and C. papaya for antimicrobial activities, and also identify the constituents of the fungal extracts using high performance liquid chromatography (HPLC).

\section{Materials and Methods}

Isolation of endophytic fungus, fermentation and extraction of metabolites

Fresh leaves of Newbouldia laevis, Ocimum gratissimum, and Carica papaya were collected from Agulu, Anambra State, Nigeria. Isolation of endophytic fungi from the plant leaves was carried out as described by Eze et al. (40). The plant leaves were washed thoroughly in running tap water and then cut into small fragments (about $1 \mathrm{~cm}^{2}$ ). The leaf fragments were surface-sterilized by immersion in $2 \%$ sodium hypochlorite solution for $2 \mathrm{~min}, 70 \%$ ethanol for nearly $2 \mathrm{~min}$, before a final rinse in sterile water for $5 \mathrm{~min}$. The leaf fragments were transferred into malt extract (ME) agar plates supplemented with chloramphenicol. The Petri plates were then incubated at a temperature of $28^{\circ} \mathrm{C}$ and fungal growths from the leaf fragments were monitored. Hyphal tips from several distinct colonies emerging from the leaf segments were sub-cultured onto fresh ME plates to obtain pure colonies. Solid state fermentation of the endophytic fungi was carried out in $1 \mathrm{~L}$ Erlenmeyer flasks containing sterile solid rice medium (100 g of rice $+100 \mathrm{~mL}$ of distilled water, autoclaved at $121^{\circ} \mathrm{C}$ at $15 \mathrm{psi}$ for $1 \mathrm{~h}$ ). The flasks were inoculated with $3 \mathrm{~mm}$ diameter agar blocks containing the respective fungi and incubated at $28^{\circ} \mathrm{C}$ for 21 days. At the completion of fermentation, the secondary metabolites (contained in the fermentation medium) were extracted with ethyl acetate, and the extracts concentrated under vacuum at $40^{\circ} \mathrm{C}$ using a rotary evaporator.

\section{Antimicrobial assay}

Preliminary antimicrobial screening of the endophytic fungal extracts was carried out using the agar well diffusion assay method as described by Akpotu et al. (41). Working concentrations $(1 \mathrm{mg} / \mathrm{mL})$ of the fungal extracts were prepared by dissolving the extracts in dimethyl sulphoxide (DMSO $100 \% \mathrm{v} / \mathrm{v})$. Standardized broth cultures of test bacterial isolates (S. aureus, S. typhi, B. subtilis, and E. coli) and fungal isolates (Candida albicans and Aspergillus fumigatus) were spread aseptically onto the surface of Mueller Hinton Agar (MHA) and Sabouraud Dextrose Agar (SDA) plates respectively using sterile cotton swabs. All culture plates were allowed to dry for about $5 \mathrm{~min}$ and agar wells were made by using a sterile cork-borer ( $6 \mathrm{~mm}$ in diameter). These wells were respectively filled with $20 \mu \mathrm{L}$ of the fungal extracts and controls. The plates were then kept at room temperature for $1 \mathrm{~h}$ to allow the agents to diffuse into the agar medium and incubated accordingly. Gentamincin $(10 \mu \mathrm{g} / \mathrm{mL})$ and ketoconazole $(50 \mu \mathrm{g} / \mathrm{mL})$ were used as positive controls in the antibacterial and antifungal evaluations respectively; while DMSO (100\% v/v) was used as the negative control. The MHA plates were then incubated at $37^{\circ} \mathrm{C}$ for $24 \mathrm{~h}$, and the SDA plates were incubated at $25-27^{\circ} \mathrm{C}$ for 2-3 days. The inhibition zones diameters (IZDs) were measured and the size of the well $(6 \mathrm{~mm})$ was deducted from the values obtained to get the actual IZDs. This was conducted in triplicate and the mean IZDs were calculated and recorded.

High performance liquid chromatography (HPLC) analysis HPLC analysis was carried on the fungal extracts was carried out as described by Eze et al. (40). A Dionex P580 HPLC system coupled to a photodiode array detector (UVD340S, Dionex Softron GmbH, Germering, Germany) was used in the analysis. The separation column $(125 \times 4 \mathrm{~mm}$; length $\times$ internal diameter) was prefilled with Eurospher-10 C18 (Knauer, Germany) and a linear gradient of nanopure water

Table 1. Result of antimicrobial assay of endophytic fungal extracts showing the inhibition zone diameters (IZDs) produced against test isolates

\begin{tabular}{|c|c|c|c|c|c|c|c|}
\hline \multirow{2}{*}{$\begin{array}{l}\text { Test } \\
\text { Organisms }\end{array}$} & \multicolumn{7}{|c|}{ IZDs (mm) } \\
\hline & NL-L1 & NL-L2 & SL-L1 & PPL-LAC & PPL-LE2 & $\begin{array}{c}\text { Positive control } \\
\text { Gentamicin }(10 \mu \mathrm{g} / \mathrm{ml})\end{array}$ & $\begin{array}{c}\text { Negative } \\
\text { control DMSO }\end{array}$ \\
\hline S. aureus & 0 & 9 & 7 & 3 & 4 & 17 & 0 \\
\hline S. typhi & 0 & 0 & 5 & 0 & 3 & 21 & 0 \\
\hline B. subtilis & 0 & 6 & 6 & 0 & 0 & 22 & 0 \\
\hline \multirow[t]{2}{*}{ E. coli } & 0 & 6 & 8 & 0 & 0 & 16 & 0 \\
\hline & & & & & & Ketoconazole $(50 \mu \mathrm{g} / \mathrm{ml})$ & DMSO \\
\hline C. albicans & 0 & 0 & 0 & 0 & 0 & 17 & 0 \\
\hline A. fumigatus & 0 & 0 & 0 & 0 & 0 & 4 & 0 \\
\hline
\end{tabular}



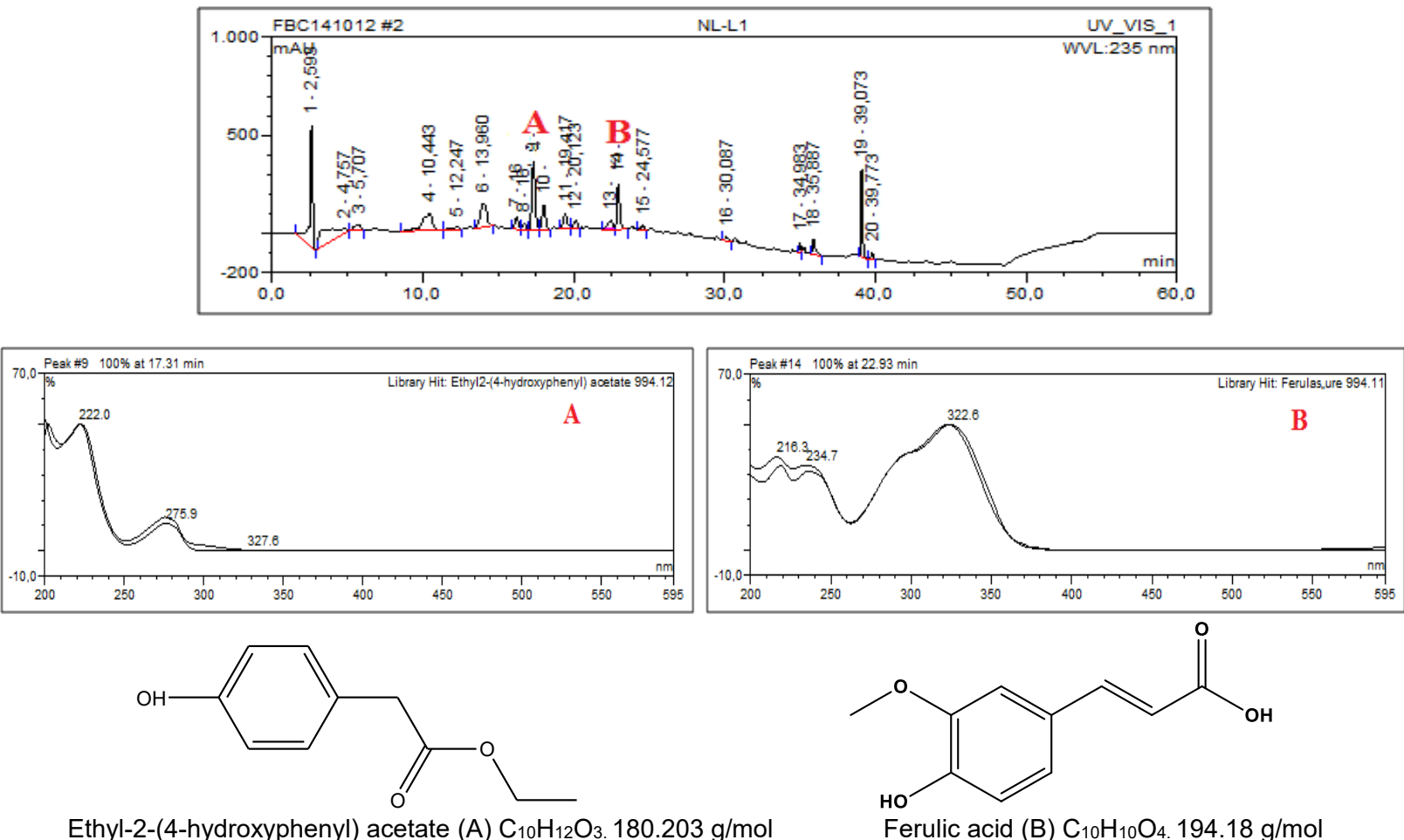

Ethyl-2-(4-hydroxyphenyl) acetate (A) $\mathrm{C}_{10} \mathrm{H}_{12} \mathrm{O}_{3} .180 .203 \mathrm{~g} / \mathrm{mol}$

Ferulic acid (B) $\mathrm{C}_{10} \mathrm{H}_{10} \mathrm{O}_{4} .194 .18 \mathrm{~g} / \mathrm{mol}$

Figure 1. HPLC chromatogram of NL-L1 extract showing ethyl-2-(4-hydroxyphenyl) acetate (A) and ferulic acid (B); their UV spectra; and structures.

(adjusted to $\mathrm{pH} 2$ by addition of formic acid) and methanol was used as eluent. A weight of $2 \mathrm{mg}$ of each fungal extract was reconstituted with $2 \mathrm{~mL}$ of HPLC grade methanol, and the mixture sonicated for $10 \mathrm{~min}$, and thereafter centrifuged at $3000 \mathrm{rpm}$ for $5 \mathrm{~min}$. A volume of $100 \mu \mathrm{L}$ of the dissolved sample was then transferred to a vial containing $500 \mu \mathrm{L}$ of HPLC grade methanol, and vial was put in the HPLC machine for analysis. Detection was at $235 \mathrm{~nm}$. The absorption peaks of the fungal extracts were analyzed by comparing with those in the HPLC-UV/Vis database.

\section{Results}

A total of five endophytic fungi was isolated, two from $N$. laevis (NL-L1 and NL-L2), one from O. gratissimum (SL-L1), and two from C. papaya (PPL-LAC and PPL-LE2). In Table 1, it can be observed that the extracts of NL-L2, SL-L1, and PPL-

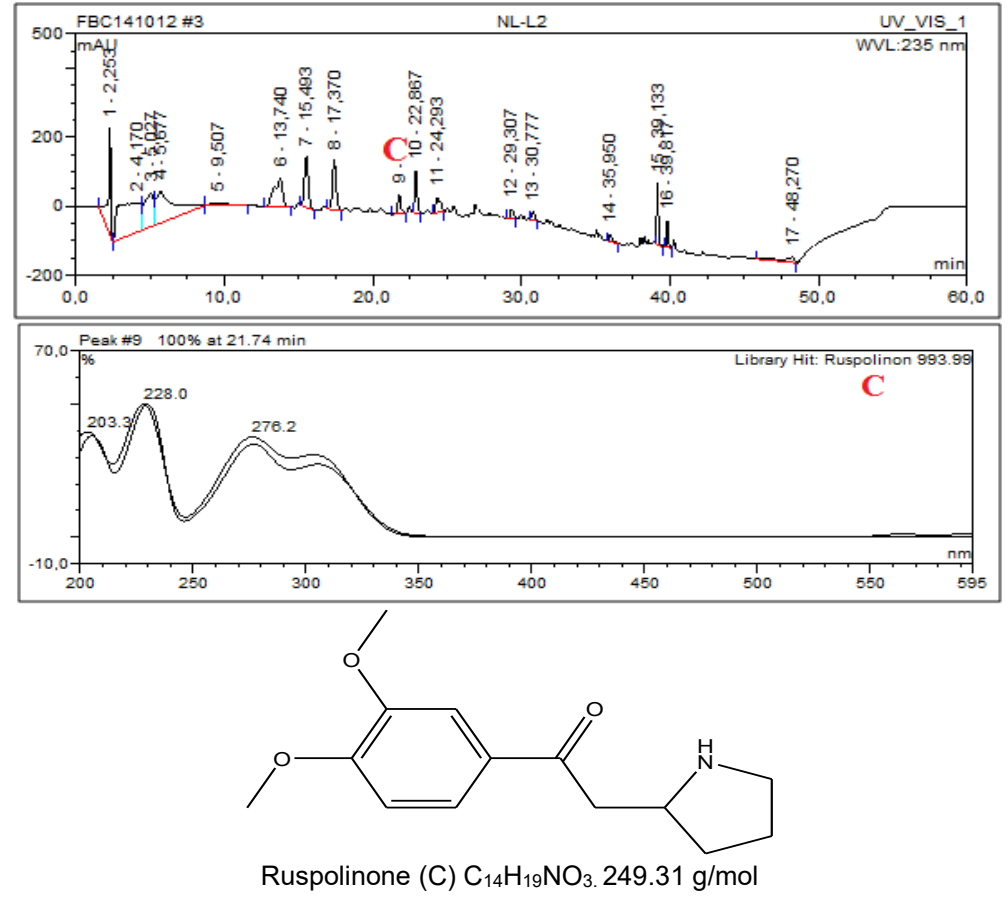

Figure 2. HPLC chromatogram of NL-L2 extract showing ruspolinone (C); its UV spectrum; and structure. 


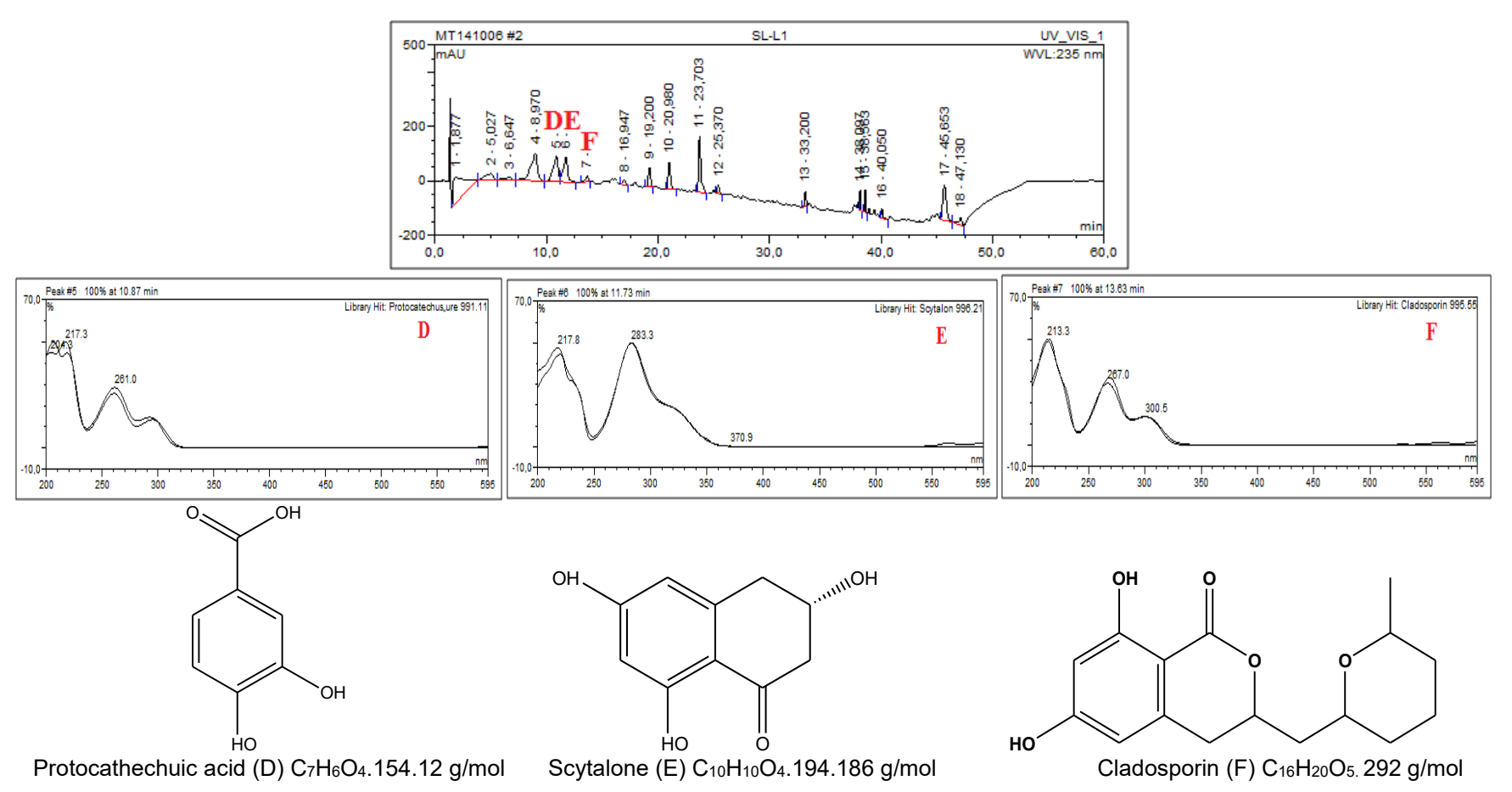

Figure 3. HPLC chromatogram of SL-L1 extract showing Protocathechuic acid (D), Scytalone (E) and Cladosporin (F); their UV spectra; and structures.

LE2 displayed antibacterial activity against both Gram negative and Gram positive test bacteria. PPL-LAC extract showed activity only against $S$. aureus, while no antimicrobial activity was recorded for NL-L1 extract. All the endophytic fungal extracts had no activity against the test fungi $C$. albicans and A. fumigatus. HPLC analysis of the fungal extracts revealed the presence of ethyl 4-hydroxyphenyl acetate and ferulic acid in NL-L1 (Fig. 1); ruspolinone in NL-L2 (Fig. 2); Protocatechuic acid, scytalone, and cladosporin in SL-L1 (Fig. 3); indole-3acetic acid and indole-3-carbaldehyde in PPL-LE2 (Fig. 4); and indole-3-acetic acid in PPL-LAC (Fig. 5).

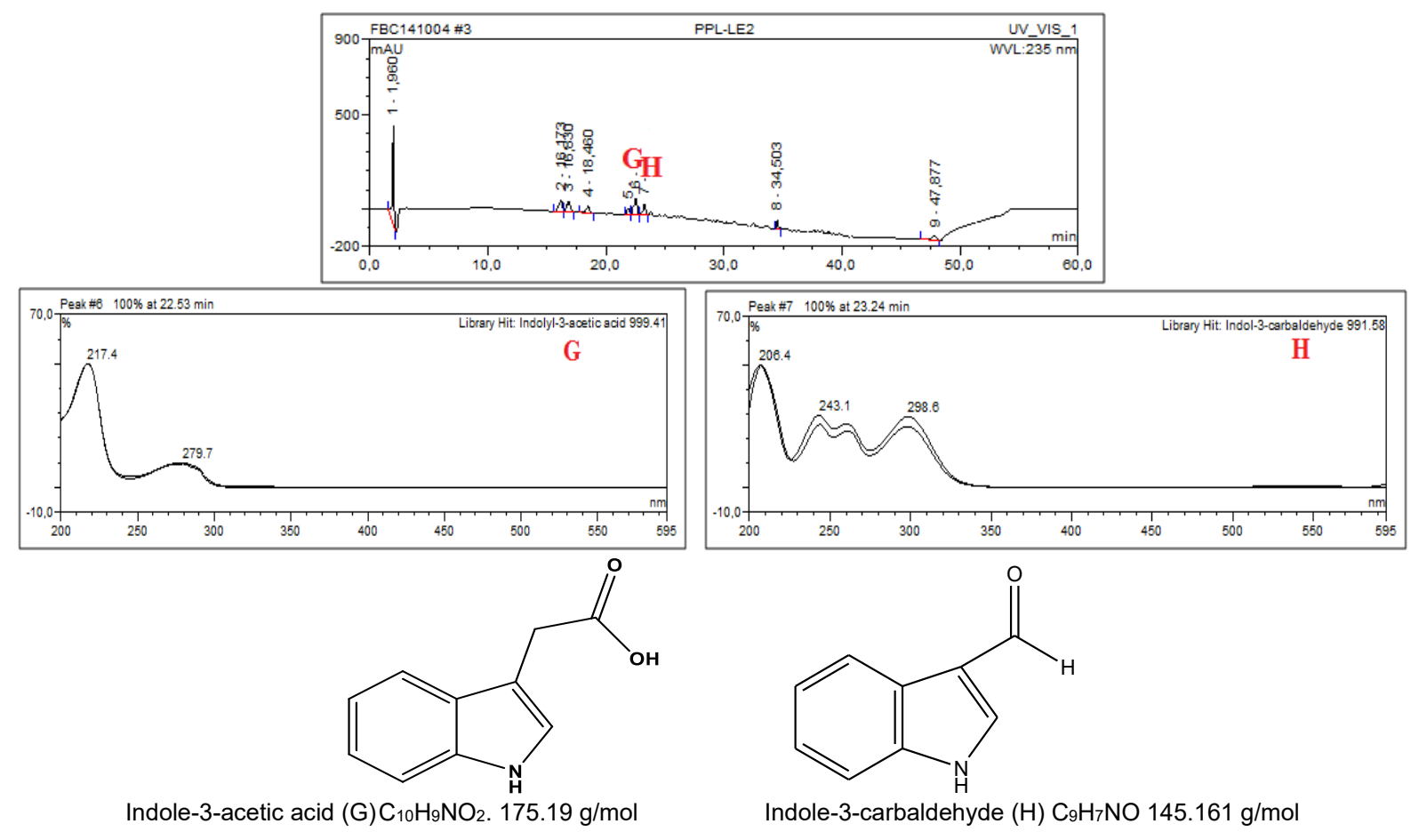

Figure 4. HPLC chromatogram of PPL-LE2 extract showing indole-3-acetic acid (G) and indole-3-carbaldehyde (H); their UV spectra; and structures. 

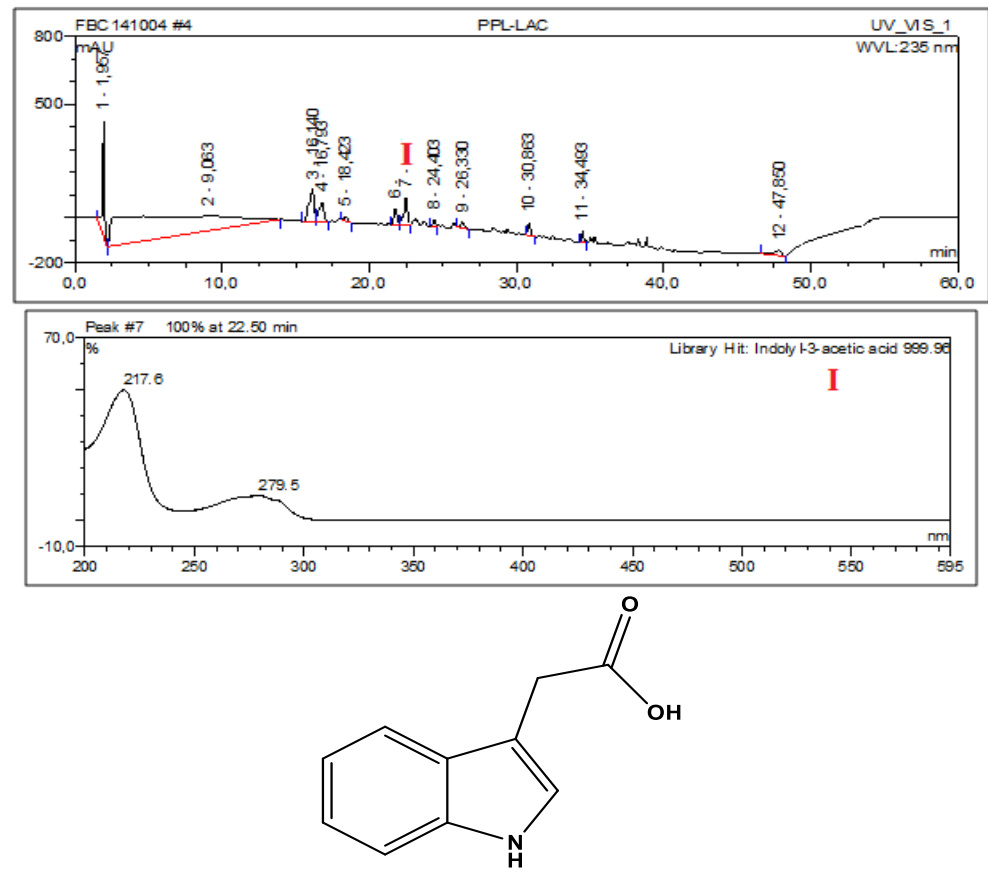

Indole-3-acetic acid (I) $\mathrm{C}_{10} \mathrm{H}_{9} \mathrm{NO}_{2} .175 .19 \mathrm{~g} / \mathrm{mol}$

Figure 5. HPLC chromatogram of PPL-LAC extract showing indole-3-acetic acid (I); its UV spectrum; and structure.

Table 2. Biological activities/applications of detected compounds

\begin{tabular}{|c|c|c|c|c|}
\hline Plants & $\begin{array}{l}\text { Endophytic } \\
\text { fungi }\end{array}$ & $\begin{array}{l}\text { Compounds detected } \\
\text { by HPLC analysis }\end{array}$ & Biological activities/applications & References \\
\hline \multirow[t]{3}{*}{$\begin{array}{l}\text { Newbouldia } \\
\text { laevis }\end{array}$} & \multirow[t]{2}{*}{ NL-L1 } & $\begin{array}{l}\text { Ethyl 4-hydroxyphenyl } \\
\text { acetate }\end{array}$ & $\begin{array}{l}\text { An intermediate for the preparation of anti- } \\
\text { inflammatory agents }\end{array}$ & (42) \\
\hline & & Ferulic acid & $\begin{array}{l}\text { Antioxidant anti-diabetic, antihypertensive, } \\
\text { anticancer, anti-inflammatory, hepatoprotective, } \\
\text { antimicrobial, anti-allergic, increase sperm viability, } \\
\text { antithrombotic, antiviral and vasodilatory actions, } \\
\text { metal chelation, modulation of enzyme activity, } \\
\text { activation of transcriptional factors, gene expression } \\
\text { and signal transduction activities }\end{array}$ & $(43-54)$ \\
\hline & NL-L2 & Ruspolinone & $\begin{array}{l}\text { Organocatalysts and building blocks in organic } \\
\text { synthesis }\end{array}$ & $(55,56)$ \\
\hline \multirow[t]{3}{*}{$\begin{array}{l}\text { Ocimum } \\
\text { gratissimum }\end{array}$} & \multirow[t]{3}{*}{ SL-L1 } & Protocatechuic acid & $\begin{array}{l}\text { Antioxidant, antimicrobial, anticancer, anti- } \\
\text { ulcer, antidiabetic, anti-ageing, antifibrotic } \\
\text { antiviral, anti-inflammatory, analgesic activity, } \\
\text { anti-atherosclerotic, cardiac, hepatoprotective, } \\
\text { neurological and nephroprotective activities }\end{array}$ & $(57-71)$ \\
\hline & & Cladosporin & $\begin{array}{l}\text { Antiplasmodial, antimicrobial, insecticidal, and } \\
\text { antitumor activities }\end{array}$ & $(72-76)$ \\
\hline & & Scytalone & $\begin{array}{l}\text { Plant growth promotion, intermediate in the } \\
\text { biosynthesis of melanin in fungi }\end{array}$ & $(77-80)$ \\
\hline \multirow{3}{*}{$\begin{array}{l}\text { Carica } \\
\text { papaya }\end{array}$} & PPL-LAC & Indole-3-acetic acid & \multirow{2}{*}{$\begin{array}{l}\text { Cytotoxic/anticancer, antioxidant, anti-inflammatory } \\
\text { activities }\end{array}$} & \multirow[t]{2}{*}{$(81-83)$} \\
\hline & \multirow[t]{2}{*}{ PPL-LE2 } & Indole-3-acetic acid & & \\
\hline & & Indole-3-carbaldehyde & $\begin{array}{l}\text { Cytotoxic and antibacterial activities, associated } \\
\text { with the innate immunity to microbial pathogen } \\
\text { infections in plants }\end{array}$ & $(84-86)$ \\
\hline
\end{tabular}




\section{Discussion}

The antibacterial activity displayed by the endophytic fungal extracts can be attributed to the antimicrobial compounds present in the extracts. As can be observed in Table 2, compounds with antimicrobial properties detected by HPLC analysis of the fungal extracts include: ferulic acid, cladosporin, indole3-carbaldehyde, and protocatechuic acid. The other detected compounds (ethyl 4-hydroxyphenyl acetate, ruspolinone, scytalone, and indole-3-acetic acid) possess diverse biological activities that include cytotoxic/anticancer, antioxidant, antiinflammatory activities, etc. (42-86).

Ferulic acid, a derivative of cinnamic acid, is a predominant natural phenolic compound first isolated from the plant Ferula foetida (45). It is present in plant seeds and leaves as a component of lignocelluloses, conferring rigidity to the cell wall by making the crosslink between polysaccharides and lignin $(45,87)$. Ferulic acid has been detected in and/or isolated from culture extracts of endophytic fungi like Annulohypoxylon stygium (88) and Aspergillus austroafricanus (89). Ferulic acid has been reported to show several pharmacological activities including antioxidant anti-diabetic, antihypertensive, anticancer, antiinflammatory, hepatoprotective, and antimicrobial activities. Other reported biological activities of ferulic acid are antiallergic, increase sperm viability, antithrombotic, antiviral and vasodilatory actions, metal chelation, modulation of enzyme activity, activation of transcriptional factors, gene expression and signal transduction activities (43-54).

Protocatechuic acid (3,4-dihydroxybenzoic acid) is a widely distributed naturally occurring phenolic acid present in most edible and medicinal plants $(53,90-92)$. The compound has also been reported to be produced by several species of bacteria and fungi $(40,57,93-95)$. Protocatechuic acid has been reported to show antioxidant, antimicrobial, anticancer, anti-ulcer, antidiabetic, anti-ageing, antifibrotic antiviral, anti-inflammatory, analgesic activity, anti-atherosclerotic, cardiac, hepatoprotective, neurological and nephroprotective activities (57-71).

Cladosporin is an isocoumarin derivative previously isolated from Cladosporium cladosporioides $(72,75)$ and Eurotium sp. (76). Cladosporin has been reported to show antiplasmodial, antimicrobial, insecticidal and antitumor activities (72-76).

Indole-3-carbaldehyde (indole-3-carboxaldehyde), an indole alkaloid, had been isolated from an endophytic Lasiodiplodia sp. associated with Viscum coloratum (96), from endophytic actinomycetes $(85,97)$, from Pseudomonas sp. (98), and from a Red Sea sponge Hyrtios erectus (86). Indole-3-carbaldehyde showed moderate cytotoxic (86) and antibacterial activities (85). In plants, indole-3-carbaldehyde is associated with the innate immunity to microbial pathogen infections $(84,85)$.

Indole-3-acetic acid is the most abundant and well known plant hormone of the auxin class which regulates various aspects of plant growth and development (99-101). Many bacterial and fungal species have been reported to be able to produce indole-3-acetic acid $(40,99,101,102)$. Indole-3acetic acid has been reported to possess cytotoxic/anticancer, antioxidant, anti-inflammatory activities (81-83).
Ethyl-2-(4-hydroxyphenyl) acetate (ethyl $p$-hydroxyphenyl acetate) has been isolated from Ixeris chinensis (103), Osmanthus fragrans (104). Ethyl p-hydroxyphenyl acetate has been used as an intermediate for the preparation of antiinflammatory agents (42).

Ruspolinone, a pyrrolidine alkaloid, was isolated from the plant Ruspolia hypercrateriformis $(105,106)$. Pyrrolidine alkaloids are hazardous for humans and animals, but exhibit a host of biological activities, and are used as organocatalysts and building blocks in organic synthesis $(55,56)$.

Scytalone, a tetralone derivative, has been previously isolated from several endophytic fungi which include Penicillium cf. glaucoalbidum (107), Cladosporium tenuissimum (108), Annulohypoxylon sp. (109), Phomopsis sp. (78), and Scytalidium sp. (110). Scytalone has been known as an intermediate in the biosynthesis of melanin, the dark pigment of many phytopathogenic fungi which aid their hyphal (appresoria) penetration into leaves and cell walls (78-80). Scytalone was also reported to promote plant growth (77).

Studies of the endophytic fungal population of Nigerian plants have revealed the potentials possessed by these plants as host to endophytes that express important biological active compounds $(2,3,40,41,111-121)$. These endophytes also hold key of possibilities to the discovery of novel molecules for pharmaceutical, agricultural and applications.

\section{Conclusion}

Endophytic fungi isolated from with three Nigerian plants Newbouldia laevis, Ocimum gratissimum, and Carica papaya produced compounds with diverse biological activities. These plants and their associated endophytes could be an excellent source of novel biologically active compounds with pharmaceutical or industrial importance.

\section{Acknowledgment}

The authors are grateful to Prof. Dr. Peter Proksch of the Institute of Pharmaceutical Biology and Biotechnology, Heinrich Heine University, Düsseldorf for assisting with the HPLC analysis.

\section{Conflict of interest statement}

The authors declare that there is no conflict of interest regarding the publication of this article.

\section{References}

1. Strobel G. The Emergence of Endophytic Microbes and Their Biological Promise. J. Fungi 2018; 4(2): 57

2. Ebada SS, Eze P, Okoye FBC, Esimone CO, Proksch P. The fungal endophyte Nigrospora oryzae produces quercetin monoglycosides previously known only from plants. Chemistry Select 2016; 1(11): 2767-2771.

3. Uzor PF, Ebrahim W, Osadebe PO, Nwodo JN, Okoye FB, Müller WEG, Lin WH, Liu Z, Proksch P. Metabolites from Combretum dolichopetalum and its associated endophytic fungus Nigrospora oryzae-Evidence for a metabolic partnership. Fitoterapia 2015; 105:147-150.

4. Silva MK, Carvalho VR, Matias EF. Chemical profile of essential oil of Ocimum gratissimum L. and evaluation of antibacterial and drug resistance-modifying activity by gaseous contact method. Pharmacognosy Journal. 2016; 8(1): 4-9. 
5. Matasyoh LG, Matasyoh JC, Wachira FN, Kinyua MG, Muigai AWT, Mukiama TK. Chemical composition and antimicrobial activity of the essential oil of Ocimum gratissimum L. growing in Eastern Kenya. Afr J Biotechnol. 2007; 6(6): 760-5.

6. Albuquerque UP, Medeiros PM, Almeida ALS, Monteiro JM, Neto EMdFL, Melo JG, dos Santos JP. Medicinal plants of the Caatinga (semi-arid) vegetation of NE Brazil: A quantitative approach. J Ethnopharma. 2007; 114(3): 325-54.

7. Adebolu T, Oladimeji SA. Antimicrobial activity of leaf extracts of Ocimum gratissimum on selected diarrhoea causing bacteria in southwestern Nigeria. Afri J Biotec. 2005; 4(7): 682-4.

8. Saeed F, Arshad MU, Pasha I, Naz R, Batool R, Khan AA, Nasir MA, Shafique B. Nutritional and Phyto-Therapeutic Potential of Papaya (Carica papaya Linn.): An Overview. International Journal of Food Properties. 2014; 17: 1637-1653.

9. Mikhalchik EV, Ivanova AV, Anurov MV, Titkova SM, Penkov LY, Kharaeva ZF, Korkina LG. Wound-healing effect of papayabased preparation in experimental thermal trauma. Bulletin of Experimental Biology and Medicine. 2004; 137: 560-562.

10. Gurunga S, Škalko-Basnet N. Wound healing properties of Carica papaya latex: In vivo evaluation in mice burn model. Journal of Ethnopharmacology. 2009; 121: 338-341

11. Kolawole OT, Akanji MA. Inhibitory effect of leaf extract of Newbouldia laevis on the metabolic activities of a-glucosidase and a-amylase. Bangladesh J Pharmacol 2013; 8: 371-377.

12. Ogunlana $\mathrm{OE}$, Ogunlana OO. In vitro assessment of antioxidant activity of Newbouldia laevis. Journal of Medicinal Plants Research, 2008; 2(8): 176-179.

13. Eyong KO, Folefoc GN, Kuete V, Beng VP, Krohn K, Hussain H, Nkengfack AE, Saeftel M, Sarite SR, Hoerauf A. Newbouldiaquinone A: A naphthoquinone-anthraquinone ether coupled pigment, as a potential antimicrobial and antimalarial agent from Newbouldia laevis. Phytochemistry 2006; 67(6): 605-9.

14. Fatunla OA, Ogundare AO, Achimugu II, Akindele PO. Antibacterial Effect of Newbouldia laevis Leaf Extract on Vancomycin and Methicillin Resistant Bacterial Isolates from Federal Medical Center, Owo. Journal of Advances in Microbiology. 2016; 1(3): 1-11.

15. Deshpande RS, Tipnis HP (1997). Insecticidal activity of Ocimum basilicum L. Pesticides 1997; 12: 21-28.

16. Chaterjee A, Sukul NC, Laskal S, Ghoshmajumdar S. Nematicidal principles from two species of Lamiaceae. Journal of Nematology 1982; 14: 118-120.

17. Bankole HA, Anjorin AA, Kazeem Ml, Ogbeche ME, Agbafor U. Antibacterial activity of Ocimum gratissimum and Gongronema latifolium on Staphylococcus aureus and Salmonella typhi. East Afri J Scienc Tech. 2012; 2(1): 114-28.

18. Ekoh SN, Akubugwo El, Ude VC, Edwin N. Anti-hyperglycemic and anti-hyperlipidemic effect of spices (Thymus vulgaris, Murraya koenigii, Ocimum gratissimum and Piper guineense) in alloxaninduced diabetic rats. Int J Biosci. 2014; 4(2): 179-87.

19. Gege-Adebayo Gl, Igbokwe VU, Shafe MO, Akintayo CO, Mbaka DI. Anti-ulcer effect of Ocimum gratissimum on indomethacin induced ulcer and percentage of superoxide dismmutase on wistar rats. J Med Med Scien. 2013; 4(1): 8-12.

20. Okoye FB, Obonga WO, Onyegbule FA, Okechukwu O, Ihekwereme CP. Chemical composition and anti-inflammatory activity of essential oils from the leaves of Ocimum basilicum L. and Ocimum gratissimum L.(Lamiaceae). Int J Pharm Sci Res. 2014; 5(6): 2174-80.

21. Lin CC, Chao PY, Shen CY, Shu JJ, Yen SK, Huang CY, Liu JY. Novel Target Genes Responsive to Apoptotic Activity by Ocimum gratissimum in Human Osteosarcoma Cells. Am J Chin Med. 2014; 42(03): 743-67.

22. Awogbindin IO, Tade OG, Metibemu SD, Olorunsogo OO, Farombi EO. Assessment of Flavonoid content, free radical scavenging and hepatoprotective activities of Ocimum gratissimum and Spondias mombin in rats treated with Dimethylnitrosamine. Arch Bas Appl Med. 2014; 2(1): 45-54.

23. Venuprasad M, Kandikattu HK, Razack S, Khanum F. Phytochemical analysis of Ocimum gratissimum by LC-ESI-MS/MS and its antioxidant and anxiolytic effects. S African J Bot. 2014; 92(1): 151 8.
24. Akpan OU, Bassey RB, Agba BS, Edegha IA. Elevation of serum pancreatic amylase and distortion of pancreatic cyto-architecture in type 1 diabetes mellitus rats treated with Ocimum gratissimum. Niger Med J. 2014; 55(1): 34.

25. Tankam JM, Ito M. Sedative, anxiolytic and antidepressant-like effects of inhalation of the essential oil of Ocimum gratissimum $\mathrm{L}$. from cameroon in mice. J Pharmacogn Phytochem. 2014; 2(5): 1-9.

26. Ojo OA, Oloyede O, Tugbobo O, Olarewaju O, Ojo A. Antioxidant and Inhibitory Effect of Scent Leaf (Ocimum gratissimum) on $\mathrm{Fe}^{2+}$ and Sodium Nitroprusside Induced Lipid Peroxidation in Rat Brain In vitro. Adv Bio Res. 2014; 8(1): 08-17.

27. Adesegun AS, Samuel FO, Anthony OB, Nurudeen OA. Antioxidant and Inhibitory Properties of Essential Oil of Ocimum Gratissimum against Extracellular Protease of Escherichia coli. losr J Pharmacy. 2013; 3(1): 50-5.

28. Amazu LU, Azikiwe CCA, Njoku CJ, Osuala FN, Nwosu PJC, Ajugwo $\mathrm{AO}$, Enye JC. Anti-inflammatory activity of the methanolic extract of the seeds of Carica papaya in experimental animals. Asi. Pac.J Trop. Med. 2010; 3(11): 884-886.

29. Mikhalchik EV, Ivanova AV, Anurov MV, Titkova SM, Penkov LY, Kharaeva ZF, Korkina LG. Wound-healing effect of papayabased preparation in experimental thermal trauma. Bulletin of Experimental Biology and Medicine. 2004; 137: 560-562.

30. Lohiya NK, Manivannan B, Mishra PK, Pathak N, Sriram S, Bhande SS, Panneerdoss S. Chloroform extract of Carica papaya seeds induces long term reversible azoospermia in langur monkey. Asian J Androl. 2004; 4(1): 17-26.

31. Poharkar RD, Saraswat RK, Kotkar S. Survey of plants having antifertility activity from western Ghat area of Maharashtra state. J Herb Med Toxicol. 2010; 4(2):71-75.

32. Stepek G, Behnke JM, Buttle DJ, Duce IR. Natural plant cysteine proteinases as anthelmintics. Trends in Parasitology. 2004; 20(7): 322-327.

33. Fauziya S, Krishnamurthy R. Papaya (Carica papaya): Source material for anticancer. CIBTech J Pharm Sci. 2013; 2(1): 25-34.

34. Doughari J, Elmahmood AM, Manzara S. Studies on the antibacterial activity of root extracts of Carica papaya L. Afr. J Microbiol. Res. 2007: 37-41.

35. Leite AA, Nardi RM, Nicoli JR, Chartone SE, Nascimento AM. Carica papaya seed macerate as inhibitor of conjugative $\mathrm{R}$ plasmid transfer from Salmonella typhimurium to E.coli, in vitro and in the digestive tract of genobiotic mice. J Gen Appl Microbiol. 2005; 51(1): 21-26

36. Koffi N, Solange TM, Emma AA, Noel ZG. Ethanobotanical study of plants used to treat arterial hypertension, in traditional medicine. European. J Scient Res. 2009; 1(1): 1-10.

37. Mojica-Henshaw MP, Francisco AD, Deguzman F, Tingo T. Possible Immunomodulatory action of Carica papaya seed extract. Clin Hemorheol Microcirc. 2003; 29(3-4): 219-229.

38. Titanji VP, Zofou D, Ngemenya MN. The Antimalarial Potential of Medicinal Plants Used for the Treatment of Malaria in Cameroonian Folk Medicine. African Journal of Traditional, Complementary and Alternative Medicines. 2008; 5 (3): 302-321.

39. Wright $\mathrm{Cl}$, Van-Buren $\mathrm{L}$, Kroner $\mathrm{Cl}$, Koning MMG. Herbal medicines as diuretics: A review of the scientific evidence. J Ethnopharmacol. 2007; 114: 1-31.

40. Eze PM, Ojimba NK, Abonyi DO, Chukwunwejim CR, Abba CC, Okoye FBC, Esimone CO. Antimicrobial Activity of Metabolites of an Endophytic Fungus Isolated from the Leaves of Citrus jambhiri (Rutaceae). Trop J Nat Prod Res. 2018, 2(3):145-149.

41. Akpotu MO, Eze PM, Abba CC, Umeokoli BO, Nwachukwu CU, Okoye FBC, Esimone CO. Antimicrobial activities of secondary metabolites of endophytic fungi isolated from Catharanthus roseus. Journal of Health Science, 2017, 7(1): 15-22.

42. Aultz DE, Helsley GC, Hoffman D, McFadden AR, Lassman HB, Wilker JC. Dibenz[b,e]oxepinalkanoic acids as nonsteroidal antiinflammatory agents. 1. 6,11-Dihydro-11-oxodibenz[b,e] oxepin-2-acetic acids. J. Med. Chem. 1977; 20 (1): 66-70.

43. Suzuki A, Kagawa D, Fujii A, Ochiai R, Tokimitsu I, Saito I. Short- and long-term effects of ferulic acid on blood pressure in spontaneously hypertensive rats. Am. J. Hypertens. 2002; 15:351-358. 
44. Ohsaki AY, Shirakawa H, Koseki T, Komai M. Novel effects of a single administration of ferulic acid on the regulation of blood pressure and the hepatic lipid metabolic profile in stroke-prone spontaneously hypertensive rats, J. Agric. Food Chem. 2008; 56:2825-2830.

45. Kumar N, Pruthi V. Structural elucidation and molecular docking of ferulic acid from Parthenium hysterophorus possessing COX-2 inhibition activity. 3 Biotech. 2015; 5(4):541-551.

46. Balasubashini MS, Rukkumani R, Viswanathan P, Menon VP. Ferulic acid alleviates lipid peroxidation in diabetic rats, Phytother. Res. 2004; 18:310-314.

47. Nomura E, Kashiwada A, Hosoda A, Nakamura K, Morishita H, Tsuno T, Taniguchi H. Synthesis of amide compounds of ferulic acid and their stimulatory effects on insulin secretion in vitro. Bioorg Med. Chem. 2003; 11:3807-3813.

48. Graf E. Antioxidant potential of ferulic acid. Free Radic. Biol. Med. 1992; 3:435-513.

49. Kikuzaki H, Hisamoto M, Hirose K, Akiyama K, Taniguchi H. Antioxidant properties of ferulic acid and its related compounds. J. Agric. Food Chem. 2002; 50:2161-2169.

50. Ou S, Kwok KC. Ferulic acid: pharmaceutical functions, preparation and applications in foods. J. Sci. Food Agric. 2004; 84: 1261-1269.

51. Sajjadi SE, Shokoohinia Y, Moayedi N. Isolation and Identification of Ferulic Acid from Aerial Parts of Kelussia odoratissima Mozaff. Jundishapur J Nat Pharm Prod. 2012; 7(4): 159-162.

52. Mori H, Kawabata K, Yoshimi N, TanakaT, Murakami T, Okada T, Murai $\mathrm{H}$. Chemopreventive effects of ferulic acid on oral and rice germ on large bowel carcinogenesis. Anticancer Res. 1999; 19 : 3775-3783.

53. Hudson EA, Dinh PA, Kokubun T, Simmonds MS, Gescher AC Characterization of potentially chemopreventive phenols in extracts of brown rice that inhibit the growth of human breast and colon cancer cells. Cancer Epidemiol. Biomark. Prev. 2000; 9(11):1163-1170.

54. El-gizawy HA, Hussein MA. Isolation, Structure Elucidation of Ferulic and Coumaric acids from Fortunella japonica Swingle leaves and their Structure Antioxidant activity relationship. Free Radicals and Antioxidants. 2017; 7(1): 23-30.

55. Roeder $\mathrm{E}$, Wiedenfeld H Plants containing pyrrolizidine alkaloids used in the traditional Indian medicine--including ayurveda. Pharmazie. 2013;68(2):83-92.

56. Bhat C, Tilve SG. Recent advances in the synthesis of naturally occurring pyrrolidines, pyrrolizidines and indolizidine alkaloids using proline as a unique chiral synthon. RSC Adv., 2014, 4, 54055452.

57. Nguyen XH, Naing KW, Lee YS, Moon JH, Lee JH, Kim KY. Isolation and characteristics of protocatechuic acid from Paenibacillus elgii HOA73 against Botrytis cinerea on strawberry fruits. J Basic Microbiol. 2015; 55(5):625-34.

58. Ciftci O, Disli OM, Timurkaan N. Protective effects of protocatechuic acid on TCDD-induced oxidative and histopathological damage in the heart tissue of rats. Toxicol Indus Health 2013; 29(9):806-811.

59. Li X, Wang X, Chen D, Chen S. Antioxidant activity and mechanism of protocatechuic acid in vitro. Funct Foods Health Dis. 2011; 7:232-244.

60. Lee JH, Lee HJ, Lee HJ, Choi WC, Yoon SW, Ko SG, Ahn KS, Choi $\mathrm{SH}$, Ahn KS, Lieske JC, Kim SH. Rhus verniciflua Stokes prevents cisplatin-induced cytotoxicity and reactive oxygen species production in MDCK-I renal cells and intact mice. Phytomed. 2009; 16(2):188-197.

61. Liu CL, Wang JM, Chu CY, Cheng MT, Tseng TH. In vivo protective effect of protocatechuic acid on tert-butyl hydroperoxide-induced rat hepatotoxicity. Food Chem Toxicol. 2002; 40(5):635-641.

62. Guan SG, Bao YM, Jiang BJ, An LJ. Protective effect of protocatechuic acid from Alpinia oxyphylla on hydrogen peroxide-induced oxidative PC12 cell death. Eur J Pharmacol. 2006; 538(1-3):73-79.

63. Li C, Jiang W, Zhu H, Hou J. Antifibrotic effects of protocatechuic aldehyde on experimental liver fibrosis. Pharm Biol. 2012; 50(4):413-419.

64. Jaijoy K, Soonthornchareonnon N, Panthong A, Sireeratawong S. Anti-inflammatory and analgesic activities of the water extract from the fruit of Phyllanthus emblica Linn. Int J Appl Res Nat Prod. 2010; 3(2):28-35

65. Borate AR, Suralkar AA, Birje SS, Malusare PV, Bangale PA Antihyperlipidemic effect of protocatechuic acid in fructose induced hyperlipidemia in rats. Int J Pharm Bio Sci. 2011; 2(4):456.

66. Tanaka T, Tanaka T, Tanaka M. Potential cancer Chemopreventive activity of protocatechuic acid. J Exp Clin. Med. 2011; 3(1):27-33.

67. Zhou Z, Zhang Y, Ding XR Chen SH, Yang J, Wang XJ, Jia GL, Chen HS, Bo XC, Wang SQ. Protocatechuic aldehyde inhibits hepatitis $B$ virus replication both in vitro and in vivo. Antivir Res. 2007; 74(1):59-64.

68. Scazzocchio B, Vari R, Filesi C, D'Archivio M, Santangelo C, Giovannini C, Lacovelli A, Silecchia G, Volti GL, Galvano F, Masella R. Cyanidin-3-O- $\beta$ - glucoside and protocatechuic acid exert insulinlike effects by upregulating PPAR $\gamma$ activity in human omental adipocytes. Diabetes 2011; 60(9):2234-2244.

69. Kore KJ, Bramhakule PP, Rachhadiya RM, Shete RV. Evaluation of anti-ulcer activity of protocatechuic acid ethyl ester in rats. Int J Pharm Life Sci. 2011; 2(7):909.

70. Shi GF, An LJ, Jiang B, Guan S, Bao YM. Alpinia protocatechuic acid protects against oxidative damage in vitro and reduces oxidative stress in vivo. Neurosci Lett. 2006; 403(3):206-210.

71. Chao CY, Yin MC. Antibacterial effects of roselle calyx extracts and protocatechuic acid in ground beef and apple juice. Foodborne Pathog Dis. 2009; 6(2):201-206.

72. Wang X, Radwan MM, Taráwneh AH, Gao J, Wedge DE, Rosa LH, Cutler HG, Cutler SJ (2013). Antifungal Activity against Plant Pathogens of Metabolites from the Endophytic Fungus Cladosporium cladosporioides. J Agric Food Chem. 61(19): 45514555.

73. Grove JF, Pople M. The insecticidal activity of some fungal dihydroisocoumarines. Mycopathologia 1981; 76:65-67.

74. Hoepfner D, McNamara CW, Lim CS, Studer C, Riedl R, Aust T, McCormack SL, Plouffe DM, Meister S, Schuierer S, Plikat U, Hartmann N, Staedtler F, Cotesta S, Schmitt EK, Petersen F, Supek F, Glynne RJ, Tallarico JA, Porter JA, Fishman MC, Bodenreider C, Diagana TT, Movva NR, Winzeler EA. (2012). Selective and specific inhibition of the Plasmodium falciparum lysyl-tRNA synthetase by the fungal secondary metabolite cladosporin. Cell Host Microbe. 11(6), 654-63

75. Xie QM, Huang JH. A preliminary study on cladosporin. Journal of Fujian College of Forestry 1988; 8:29-36.

76. Anke $\mathrm{H}$, Zähner $\mathrm{H}$. Metabolic products of microorganisms 170 . On the antibiotic activity of cladosporin. Arch Microbiol 1978; 116(3):253-7.

77. Abou-Mansour E, Couché E, Tabacchi R. Do fungal naphthalenones have a role in the development of Esca symptoms. Phytopathol. Mediterr. 2004; 43:75-82.

78. Weber D, Gorzalczany S, Martino V, Acevedo C, Sterner O, Anke T. Metabolites from endophytes of the medicinal plant Erythrina crista-galli. Z. Naturforsch. 2005; 60c: 467-477.

79. Bell AA, Wheeler MH. Biosynthesis and function of fungal melanins. Annu. Rev. Phytopathol 1986; 24: 411-451.

80. Langfelder K, Streibel M, Jahn B, Haase G, Brakhage AA. Biosynthesis of fungal melanins and their importance for human pathogenic fungi. Fungal Genet. Biol. 2003; 38: 143-158.

81. Wardman P. Indole-3-acetic acids and horseradish peroxidase: a new prodrug/enzyme combination for targeted cancer therapy. Curr Pharm Des 2002; 8(15):1363-1374.

82. Jeong YM, Oh MH, Kim SY, Li H, Yun HY, Baek KJ, Kwon NS, Kim WY, Kim DS. Indole-3 acetic acid/horseradish peroxidase induces apoptosis in TCCSUP human urinary bladder carcinoma cells. Pharmazie 2010; 65(2):122-126.

83. Jones LH, Abdalla DSP, Freitas JC. Effects of indole-3-acetic acid on croton oil and arachidonic acid-induced mouse ear edema. Inflamm Res 1995; 44(9):372-375.

84. Stahl E, Bellwon P, Huber S, Schlaeppi K, Bernsdorff F, Vallat- Michel A., Mauch F, Zeier J (2016). Regulatory and functional aspects of Indolic metabolism in plant systemic acquired resistance. Mol. Plant. 9, 662-681.

85. Gos FMWR, Savi DC, Shaaban KA, Thorson JS, Aluizio R, Possiede 
YM, Rohr J and Glienke C (2017) Antibacterial Activity of Endophytic Actinomycetes Isolated from the Medicinal Plant Vochysia divergens (Pantanal, Brazil). Front. Microbiol. 8:1642.

86. Ashour MA, Elkhayat ES, Ebel R, Edrada R, Proksch P. Indole alkaloid from the Red Sea sponge Hyrtios erectus. ARKIVOC 2007 (xv): 225231

87. Rosazza JPN, Huang Z, Dostal L, Volm T, Rousseau B. Review: Biocatalytic transformations of ferulic acid: an abundant aromatic natural product. J. Ind. Microbiol. 1995; 15: 457-471.

88. Cheng M, Wu M, Chen J, Cheng Y, Hsieh M, Hsieh S, Yuan G, Su Y. Secondary Metabolites from the Endophytic Fungus Annulohypoxylon stygium BCRC 34024. Chemistry of Natural Compounds. 2014; 50(2): 237-241.

89. Danagoudar A, Joshi CG, Kumar SR, Poyya J, Nivya T, Hulikere MM Appaiah KAA. Molecular profiling and antioxidant as well as antibacterial potential of polyphenol producing endophytic fungusAspergillus austroafricanus CGJ-B3, Mycology. 2017; 8(1): 28-38.

90. Liu RH. Potential synergy of phytochemicals in cancer prevention: mechanism of action. The Journal of Nutrition. 2004; 134(12): 3479S-3485S

91. Masella R, Cantafora A, Modesti D, Cardilli A, Gennaro L, Bocca A, Coni E. Antioxidant activity of 3,4-DHPEA-EA and protocatecuic acid: a comparative assessment with other olive oil biophenols. Redox Rep. 1999; 4(3):113-121.

92. Kayano Sl, Kikuzaki H, Fukutsuka N, Mitani T, Nakatani N. Antioxidant activity of prune (Prunus domestica L.) constituents and a new synergist. J Agric Food Chem. 2002; 50(13):3708-3712.

93. Lee YS, Kang Y, Jung J, Lee S, Ohuchi K, Shin KH, Kang I, Park $J H Y$, Shin $\mathrm{H}$, Lim SS. Protein glycation inhibitors from the fruiting body of Phellinus linteus. Biological \& Pharmaceutical Bulletin. 2008; 31 (10): 1968-72.

94. Signore A, Romeo F, Giaccio M. Content of phenolic substances in basidiomycetes. Mycological Research. 1997; 101 (5): 552-6.

95. Williams KM, Martin WE, Smith J, Williams BS, Garner BL. Production of Protocatechuic Acid in Bacillus Thuringiensis ATCC33679. Int. J. Mol. Sci. 2012, 13, 3765-3772.

96. Qian C, Fu Y, Jiang F, Xu Z, Cheng D, Ding B, Gao C, Ding Z. Lasiodiplodia sp. ME4-2, an endophytic fungus from the floral parts of Viscum coloratum, produces indole-3-carboxylic acid and other aromatic metabolites. BMC Microbiology 2014, 14:297

97. Savi DC, Shaaban KA, Vargas N, Ponomareva LV, Possiede YM, Thorson JS, Glienke C, Rohr J. Microbispora sp. LGMB259endophytic actinomycete isolated from Vochysia divergens (Pantanal, Brazil) producing Bcarbolines and indoles with biological activity. Cur. Microbiol. 2015; 70: 345-354.

98. Zendah I, Shaaban KA, Helmke E, Maier A, Fiebig H, Laatsch H. Barakacin: A thiazolyl-indole alkaloid isolated from a ruminal Pseudomonas sp. Z. Naturforsch. 2012; 67, 417-420.

99. Fu S, Wei J, Chen H, Liu Y, Lu H, Chou J. Indole-3-acetic acid: A widespread physiological code in interactions of fungi with other organisms. Plant Signal Behav. 2015; 10(8):e1048052.

100. Teale WD, Paponov IA, Palme K. Auxin in action: signalling, transport and the control of plant growth and development. Nat Rev Mol Cell Biol. 2006; 7:847-859.

101. Spaepen S, Vanderleyden J, Remans R. Indole-3-acetic acid in microbial and microorganism-plant signaling. FEMS Microbiol Rev. 2007; 31(4):425-448.

102. Leveau JHJ and Lindow SE. Utilization of the Plant Hormone Indole-3-Acetic Acid for Growth by Pseudomonas putida Strain 1290. Appl. Environ. Microbiol. 2005; 71(5): 2365-2371

103. Zhang SJ, Wang D, XUu C, Wang JL, Zhao M. Chemical constituents from roots of Ixeris chinensis. Zhongguo Zhong Yao Za Zhi. 2014; (16):3089-93

104. Yin W, Song ZR, Liu JQ, Zhang GS. Chemical constituents of Osmanthus fragrans. Zhongguo Zhong Yao Za Zhi. 2015; 40(4):67985.

105. Roessler F, Ganzinger D, Johne S, Schöpp E, Hesse M. Ruspolia hypercrateriformisM.R.: Isolierung und Strukturaufklärung von neuen Pyrrolidin-Alkaloiden. 169. Mitt. über organische Naturstoffe. HCA, 1978; 61: 1200-1206.

106. Jones K, Woo K. A Total Synthesis of (-)-Ruspolinone. Tetrahedron.
1991; 47(34):7179-7184.

107. Daly GJ. Isolation and Characterization of Biologically Active Secondary Metabolites Produced by Foliar Endophytes of Red and Black Spruce from the Acadian Forest. Master of Science degree thesis submitted to the Department of Chemistry, Carleton University. 2017.

108. Naseer S, Bhat KA, Qadri M, Riyaz-UI-Hassan S, Malik FA, Khuroo MA. Bioactivity-Guided Isolation, Antimicrobial and Cytotoxic Evaluation of Secondary Metabolites from Cladosporium tenuissimum Associated with Pinus wallichiana. Chemistry Select. 2017; 2(3): 1311-1314

109. Liu Y, Stuhldreier F, Kurtán T, Mándi A, Arumugam S, Lin W, Stork B, Wesselborg S, Weber H, Henrich B, Daletos G, Proksch P. Daldinone derivatives from the mangrove-derived endophytic fungus Annulohypoxylon sp. RSC Adv. 2017; 7: 5381 -5393.

110. Findlay JA, Kwan D. Scytalone (3,6,8-Trihydrozytetralone), a metabolite from a Scytalidium Species. Can. J. Chem. 1972; 51: 1617-1619.

111. Okoye FBC, Lu S, Nworu CS, Esimone CO, Proksch P, Chaldi A. Debbab A. Depsidone and Diaryl Ether Derivatives from the Fungus Corynespora cassiicola, an Endophyte of Gongronema latifolium. Tetrahedron Letters 2013; 54: 4210-4214.

112. Okoye FBC, Nworu CS, Akah PA, Esimone CO, Debbab A, Proksch P. Inhibition of inflammatory mediators and reactive oxygen and nitrogen species by some depsidones and diaryl ether derivatives isolated from Corynespora cassiicola, an endophytic fungus of Gongronema latifolium leaves. Immunopharmacology and Immunotoxicology 2013; 35(6): 662-668.

113. Okoye FBC, Nworu CS, Debbab A, Esimone CO, Proksch P. Two new Cytochalasins from an endophytic fungus, $\mathrm{KL}-1.1$ isolated from Psidium guajava leaves. Phytochemistry Letters, 2015, 14:51-55.

114. Abba CC, Nduka I, Eze PM, Ujam TN, Abonyi DO, Okoye FBC. Antimicrobial Activity of Secondary Metabolites of Endophytic Aspergillus Species Isolated from Loranthus micranthus. African Journal of Pharmaceutical Research and Development 2016; 8(2): 136-140.

115. Chen H, Daletous G, Okoye FBC, Lai D, Dai H, Proksch P. A new cytotoxic cytochalasin from the endophytic fungus Trichodama harzianum. Natural Products Communications 2015; 10(4): 585-587.

116. Okezie UM, Eze PM, Okoye FBC, Ikegbunam MN, Ugwu MC, Esimone CO. Biologically Active Metabolites of an Endophytic Fungus Isolated from Vernonia Amygdalina. African Journal of Pharmaceutical Research and Development 2017; 9(1): 24-29.

117. Abba CC, Eze PM, Abonyi DO, Nwachukwu CU, Proksch $P$, Okoye FBC, Eboka CJ. Phenolic Compounds from Endophytic Pseudofusicoccum sp. Isolated from Annona muricata. Trop J Nat Prod Res. 2018; 2(7):332-337.

118. Nwachukwu CU, Ngwoke KG, Eze PM, Eboka CJ, Okoye FBC. Secondary Metabolites from Curvularia sp, An Endophytic Fungus Isolated from the Leaves of Picralima nitida Durand and Hook (Apocynaceae). Trop J Nat Prod Res. 2018; 2(5):209-213.

119. Nnanna JC, Eze PM, Anyanwu OO, Ujam TN, Ikegbunam MN, Okoye FBC, Esimone CO. Screening of Metabolites of Endophytic Fungi Isolated from Leaves of Azadirachta indica for Antimicrobial and Cytotoxic Activities. The Pharmaceutical and Chemical Journal, 2018; 5(3): 20-27

120. Wang H, Eze PM, Höfert S, JaniakC, Hartmann R, Okoye FBC, Esimone CO, Orfali RS, Dai H, Liu Z, Proksch P. Substituted L-tryptophan-Lphenyllactic acid conjugates produced by an endophytic fungus Aspergillus aculeatus using an OSMAC approach. RSC Adv. 2018; 8:7863-7872.

121. Abonyi DO, Eze PM, Abba CC, Ujam, NT, Proksch P, Okoye FBC, Esimone CO. Biologically active phenolic acids produced by Aspergillus sp., an endophyte of Moringa oleifera. Euro J Biol Res 2018; 8(3): 158-168. 